\title{
Perspektywa rozwoju pedagogiki specjalnej w tyglu jej dualnego i dwoistego charakteru
}

\begin{abstract}
Abstrakt
Na strukturę artykułu składają się cztery części. W pierwszej zostały przedstawione uwarunkowania rozwoju pedagogiki specjalnej jako subdyscypliny pedagogiki. Część drugą otwiera teza o dualnym charakterze rozwoju pedagogiki specjalnej (jest to charakterystyka jej głównych nurtów: pierwszego związanego przede wszystkim z naukami medycznymi, drugiego - z naukami humanistycznymi i społecznymi). Część trzecia to ukazanie dwoistości pedagogiki specjalnej jako subdyscypliny stosowanej $\mathrm{w}$ relacji teorii do praktyki. W ostatniej części, stanowiącej zakończenie, została przedstawiona perspektywa rozwoju pedagogiki specjalnej w kontekście międzydyscyplinarnej i międzyparadygmatycznej wędrówki pojęć. Jako przykład wędrówki zostały przywołane koncepcje niepełnosprawności intelektualnej. Przeobrażenia te zostały przedstawione jako szansa na znoszenie wskazanych niewspółmierności charakteryzujących dualny rozwój i dwoisty charakter pedagogiki specjalnej.
\end{abstract}

Słowa kluczowe: pedagogika specjalna, dwoistość, dualność, perspektywa rozwoju.

\section{The developmental prospects of special education in the melting pot of its dual and double character}

\begin{abstract}
The article consists of four parts. The first part presents the developmental determinants of special education as a subdiscipline of pedagogy. The second opens with the thesis on the dual character of the development of special education (this involves the description of its major currents - the first mostly associated with medical sciences and the second - with humanities and social sciences). The third part focuses on the doubleness of special education as a sub-discipline used in the theoryto-practice relationship. The final part displays the developmental prospects of special education in the context of the interdisciplinary and interparadigmatic migration of notions. This migration is exemplified by the concepts of intellectual disability.
\end{abstract}

\footnotetext{
* Uniwersytet Śląski w Katowicach.
} 
These transformations have been shown as an opportunity to eliminate the indicated incommensurabilities characterizing the dual development and the dual nature of special education.

Keywords: special education, dualism, doubleness, developmental prospects.

\section{Wprowadzenie}

Rozwój pedagogiki specjalnej w ostatnich dekadach warunkowany był kilkoma czynnikami. Pierwszy, i być może najważniejszy, to wzrost zainteresowania społecznego problemem niepełnosprawności, ukierunkowany na włączanie osób nią obarczonych (także niedostosowanych społecznie z innych niż niepełnosprawność przyczyn) w główne nurty życia społecznego. W czynnik ten wpisują się również wszelkie działania służące poprawie jakości życia osób będących z różnych powodów w sytuacjach nieprzeciętnych, zwykle niekorzystnie wpływających na ich codzienność. Dążenia te zaowocowały wieloma formalnymi i nieformalnymi projektami ekonomicznymi, prawnymi, społecznymi, których istota zasadzała się na praktykach (koncepcjach, ideach) wypracowanych na gruncie nauk o niepełnosprawności i niedostosowaniu społecznym, w tym także pedagogiki specjalnej. Drugi istotny czynnik rozkwitu omawianej subdyscypliny pedagogicznej to skokowy postęp technologiczny w wielu dziedzinach życia. Otworzył on nowe pola badawcze, umożliwił nowatorskie dociekania empiryczne także w zakresie zastanych (wyczerpanych tematycznie) obszarów. Trzeci, w moim przekonaniu nie mniej ważny czynnik warty wyeksponowania, to przeobrażenia dyskursów oraz metodologii i metodyki badań w naukach humanistycznych i społecznych. Inspirowały one i inspirują nadal przedstawicieli pedagogiki specjalnej do intensywnych konwersacji wewnętrznych oraz sprzyjają szerszemu otwieraniu się problematyki pedagogiki specjalnej na idee, koncepcje, teorie pozornie z nią niezwiązane.

Przedstawione (w uproszczeniu, przez co i nieco zbanalizowane) uwarunkowania rozwoju pedagogiki specjalnej zachęcają do refleksji nad perspektywami jej rozwoju i pytaniami o jej tożsamość, a zarazem role i zadania w kreowaniu praktyk społecznych. Podejmując próbę krótkiego zarysu wskazanych perspektyw, korzystam z kategorii dualizmu i dwoistości. Pierwszą kategorię odnoszę do rozwoju tożsamości pedagogiki specjalnej, drugą - do jej statusu jako subdyscypliny stosowanej, czasem też określanej mianem praktycznej.

\section{Dualna tożsamość pedagogiki specjalnej}

Rozważania na temat tożsamości dyscypliny naukowej traktowane bywają kontrowersyjnie. Z jednej strony przypisuje się im cechy egocentryzmu, infantylizmu, megalomanii czy symptomów kompleksów środowiska naukowego uprawiającego 
daną dyscyplinę. Z drugiej - refleksja nad tożsamością dyscypliny bywa postrzegana jako element kształtowania się samoświadomości istotnych wyznaczników jej rozwoju, m.in. jej obszaru, zadań czy metodologii (Lewowicki 2012: 11; Hejnicka-Bezwińska 2013: 36). Namysł nad tożsamością dyscypliny może zostać sprokurowany także niepokojem o jej dysharmonijne przemiany (Zaczyński 1988: 5) lub próbą zidentyfikowania i wyjaśnienia źródeł jej wewnętrznego zróżnicowania i przewidywania możliwych dróg dalszego rozwoju. Nie wgłębiając się w przywołane spory, przyjmuję ostatnią propozycję jako punkt wyjścia nad tożsamością pedagogiki specjalnej.

Dualność traktuję jako istnienie obok siebie dwóch odrębnych, niezależnych od siebie zjawisk w jednej rzeczywistości (Słowik języka polskiego, t. 1, 1992: 464-465). Zakładam, że w odniesieniu do nurtów naukowych mogą się one rozwijać niezalenie od siebie w obszarze jednej dyscypliny i być wobec siebie konkurencyjne.

Parafrazując koncepcję Margaret S. Archer (2013: 290-296) rozwoju tożsamości osobistej opartej na trzech źródłach doświadczania porządków: naturalnego, praktycznego, społecznego, przyjmuję, że:

- tożsamość pedagogiki specjalnej rozwija się na bazie doświadczeń (rozumianych jako osiąganie statusu nauki oraz realizacja zadań społecznych),

- tożsamość subdyscypliny warunkuje wybór jej roli w relacji do innych nauk oraz praktyk społecznych,

- zasoby ukonstytuowane na doświadczeniach nie mają trwałego charakteru,

- w ramach wewnętrznej konwersacji na gruncie pedagogiki specjalnej prowadzony jest dyskurs służący zdefiniowaniu jej celu i zadań w kontekście zmieniającej się rzeczywistości,

- konwersacja jest nieustannie rewidowana w toku kolejnych doświadczeń,

- trafność (rozpatrywana w kategoriach rosnącego uznania statusu jako nauki oraz przydatności społecznej) zdefiniowanej roli jest wprost proporcjonalna do jakości prowadzonej konwersacji wewnętrznej - inaczej ujmując - rozwój pedagogiki specjalnej jako subdyscypliny naukowej stosowanej w praktyce warunkowany jest intensywnością i jakością wewnętrznych dyskusji.

Przywołaną koncepcję (dotyczącą w oryginalnej postaci rozwoju osobistego jednostki) traktuję jedynie jako narzędzie porządkujące sposób myślenia o rozwoju pedagogiki specjalnej, a nie jako model stanowiący gotowy wzór prowadzonych rozważań. Ukazuje ona dynamiczny charakter tożsamości, a podstawą jej przemian jest doświadczenie oraz konwersacja.

Wewnętrzną konwersację ( $w$ tym ujęciu) utożsamiam z dyskusją pedagogów specjalnych na temat statusu, zadań i perspektyw rozwoju omawianej dyscypliny także z wykorzystaniem stanowisk przedstawicieli innych dyscyplin naukowych. Naturalnie, z racji ograniczonych ram opracowania, odnoszę się jedynie do wybranych obszarów przywołanej koncepcji. 
Doświadczenia pedagogiki specjalnej w zakresie konstytuowania się jej podstaw naukowych wpisują się w drogi rozwoju pedagogiki i jej innych, głównych subdyscyplin. Po okresach okrzepnięcia (gruntowania jej podstaw i zakreślenia teoretycznych ram) następowały etapy ożywionych dyskusji nad jej autonomią, szczególnie w relacji do pedagogiki, okazjonalnie także innych dyscyplin naukowych (m.in. Doroszewska 1989; Dykcik 1998; Lewowicki 2000; Dykcik 2005; Gajdzica 2010; Krause 2010). W kwestii tej widoczne są dwa odrębne stanowiska, dążące do:

- akcentowania odrębności pedagogiki specjalnej (poszukiwania jej statusu ukierunkowanego na osiągnięcie „dyscyplinarnej niepodległości”); zwolennicy tego podejścia uwydatniają związki pedagogiki specjalnej z naukami medycznymi, częściowo także psychologią (szczególnie kliniczną), doceniają funkcjonalne koncepcje niepełnosprawności i niedostosowania społecznego, częściej dostrzegają wartość badań ulokowanych w paradygmacie pozytywistycznym;

- uwydatniania jej związków z pedagogiką (ukierunkowane na umocnienie jej statusu jako subdyscypliny rozwijającej się na kanwie ogólnej wiedzy pedagogicznej); zwolennicy tego stanowiska częściej korzystają z dorobku nauk humanistycznych (filozofii, kulturoznawstwa) i społecznych (socjologii, antropologii społecznej, psychologii społecznej), uznają za wiodące społeczne koncepcje niepełnosprawności i niedostosowania, osadzają projekty badawcze w paradygmacie pozytywistycznym jak i w paradygmatach interpretatywnych.

Podejścia te stanowią podstawę wielu koncepcji funkcjonowania osób z niepełnosprawnością / niedostosowaniem społecznym, postrzegania ucznia, organizacji szkoły czy metod nauczania. Na ogół są one formułowane w opozycji do siebie, co obrazują przykładowe zestawienia w tabeli 1 i 2 .

Tabela 1. Medyczny i społeczny model niepełnosprawności w szkole

\begin{tabular}{|l|l|}
\hline \multicolumn{1}{|c|}{ Model medyczny } & \multicolumn{1}{c|}{ Model społeczny } \\
\hline Uczeń jest niesprawny & Uczeń jest wartością \\
\hline Diagnoza & $\begin{array}{l}\text { Mocne strony i potrzeby określone przez } \\
\text { siebie i innych }\end{array}$ \\
\hline Etykietowanie & $\begin{array}{l}\text { Identyfikacja barier i rozwiązań służących } \\
\text { rozwojowi }\end{array}$ \\
\hline Skupienie uwagi na uszkodzeniu & Zaprojektowanie programu \\
\hline $\begin{array}{l}\text { Program terapii jest narzucony i monito- } \\
\text { rowany }\end{array}$ & Zasoby są dostarczane przez zwykłe usługi \\
\hline Segregacja i alternatywne usługi & Szkolenie rodziców i profesjonalistów \\
\hline Zwykłe potrzeby ograniczane & Pielęgnowanie partnerstwa \\
\hline Osiągnięcie normy lub ekskluzja & Akceptowane zróżnicowanie \\
\hline Społeczeństwo pozostaje niezmienione & Społeczeństwo ewoluuje \\
\hline
\end{tabular}

Źródło: Rieser 2013: 139. 
Konstruowanie tego typu zestawień zwykle zasadza się na kanwie relacji dwóch modeli niepełnosprawności: medycznego (łączonego z nim modelu indywidualnego) i społecznego. Przy czym częściej zestawienia te opracowywane są przez zwolenników paradygmatów humanistycznych, w związku z tym - z reguły przesadnie - akcentują one negatywne strony koncepcji medycznych. Przykład takiej relacji został zaprezentowany w tabeli 1 . Ukazuje on społeczny model niepełnosprawności jako kolejny etap rozwoju myślenia o socjalizacji i edukacji osób z niepełnosprawnością, a zarazem tworzy podstawy do myślenia o procesach inkluzji (społecznej i edukacyjnej) jako konstruktach nadbudowanych na doświadczeniach nie tylko separacyjnych, ale także integracyjnych. W wyniku tych przeobrażeń pojawia się koncepcja kultury inkluzyjnej szkoły, a w jej obrębie postrzegania ucznia z niepełnosprawnością (zob. tabela 2).

Tabela 2. Kultura edukacyjna oparta na modelu medycznym i społecznym

\begin{tabular}{|l|l|l|}
\hline \multicolumn{1}{|c|}{$\begin{array}{c}\text { Kryterium } \\
\text { porównania }\end{array}$} & \multicolumn{1}{|c|}{$\begin{array}{c}\text { Kultura edukacyjna oparta } \\
\text { na indywidualnym modelu } \\
\text { niepełnosprawności }\end{array}$} & \multicolumn{1}{|c|}{$\begin{array}{c}\text { Kultura edukacyjna oparta } \\
\text { na społecznym modelu } \\
\text { niepełnosprawności }\end{array}$} \\
\hline $\begin{array}{l}\text { Podejście do } \\
\text { specjalnych } \\
\text { potrzeb ucznia }\end{array}$ & Obciążenie & Wyzwanie \\
\hline $\begin{array}{l}\text { Źródło specjal- } \\
\text { nych potrzeb }\end{array}$ & $\begin{array}{l}\text { Konsekwencja zaburzeń } \\
\text { funkcjonalnych }\end{array}$ & $\begin{array}{l}\text { Nieadekwatne oczekiwania, niedo- } \\
\text { stosowanie programu kształcenia }\end{array}$ \\
\hline $\begin{array}{l}\text { Istota specjalnych } \\
\text { potrzeb }\end{array}$ & $\begin{array}{l}\text { Trudności w realizowaniu } \\
\text { celów kształcenia i wychowa- } \\
\text { nia }\end{array}$ & $\begin{array}{l}\text { Poszukiwanie optymalnych dróg } \\
\text { rozwoju }\end{array}$ \\
\hline $\begin{array}{l}\text { Przestrzeń } \\
\text { zjawiska }\end{array}$ & Wymiar osobisty & W organizacji pracy lekcyjnej i szkoły \\
\hline Rola ucznia & $\begin{array}{l}\text { Uczeń niepełnosprawny } \\
\text { wymagający specjalnej pomocy }\end{array}$ & $\begin{array}{l}\text { Uczeń nieprzeciętny wymagający } \\
\text { racjonalnego wspierania i unikatowej } \\
\text { organizacji procesu edukacji }\end{array}$ \\
\hline Rozwiązanie & $\begin{array}{l}\text { Fachowa interwencja specjali- } \\
\text { stów, indywidualizacja, kiedy } \\
\text { to możliwe, specjalna pomoc }\end{array}$ & $\begin{array}{l}\text { Edukacja na miarę możliwości, } \\
\text { dostosowanie, usunięcie barier, } \\
\text { indywidualizacja, kiedy to konieczne }\end{array}$ \\
\hline $\begin{array}{l}\text { Kontrola } \\
\text { Wyniki osiągnięć szkolnych } \\
\text { w aspekcie wymagań progra- } \\
\text { mowych }\end{array}$ & $\begin{array}{l}\text { Ocena postępów - rozwoju umiejęt- } \\
\text { ności i kompetencji }\end{array}$ \\
\hline $\begin{array}{l}\text { Adaptacja do wymagań } \\
\text { szkolnych }\end{array}$ & $\begin{array}{l}\text { Akceptacja możliwości, dopasowanie } \\
\text { oczekiwań - zmiana organizacji }\end{array}$ \\
\hline
\end{tabular}

Źródło: opracowanie własneำ.

1 W opracowaniu wykorzystałem kryteria porównania z pracy modeli medycznego i społecznego autorstwa: M. Piasecki, S. Besowski, R. Czech (1998: 48). 
Pomijam jej charakterystykę, ograniczając się do prezentacji zestawienia jako pewnego rodzaju uogólnienia omawianych przemian, których podstawą jest traktowanie różnorodności jako normy, a ucznia z niepełnosprawnością jako wyzwanie dla działań edukacyjnych. W konsekwencji można dostrzec także dwa różne założenia postrzegania istoty praktyk edukacyjnych. W pierwszym przypadku jest ono osadzone w dydaktyce quasi-behawioralnej, a w drugim - nawiązuje do dydaktyki konstruktywistycznej (zob. tabela 3). Warto jednak wspomnieć, że te drugie przenikają do codzienności szkoły z ogromną trudnością.

Tabela 3. Wybrane kategorie praktyk społecznych w dwóch koncepcjach kształcenia uczniów z niepełnosprawnością

\begin{tabular}{|l|l|l|}
\hline $\begin{array}{l}\text { Wybrane kategorie } \\
\text { praktyk społecznych }\end{array}$ & $\begin{array}{l}\text { Dydaktyka tradycyjna oparta } \\
\text { na modelu funkcjonalnym } \\
\text { niepełnosprawności }\end{array}$ & $\begin{array}{l}\text { Dydaktyka konstruktywistyczna } \\
\text { oparta na modelu społecznym } \\
\text { niepełnosprawności }\end{array}$ \\
\hline $\begin{array}{l}\text { Realizowanie } \\
\text { specjalnych potrzeb }\end{array}$ & $\begin{array}{l}\text { Skierowane na ucznia, } \\
\text { w związku z ich źródłem }\end{array}$ & $\begin{array}{l}\text { Skierowane na warunki uczenia } \\
\text { się, w związku z procesem ich } \\
\text { zaspokajania }\end{array}$ \\
\hline Dopasowywanie & $\begin{array}{l}\text { Ukierunkowane na proces } \\
\text { uczenia się }\end{array}$ & $\begin{array}{l}\text { Ukierunkowane na zmianę } \\
\text { warunków uczenia się }\end{array}$ \\
\hline Wspieranie & $\begin{array}{l}\text { Przede wszystkim w trakcie } \\
\text { lekcji }\end{array}$ & $\begin{array}{l}\text { W znacznym zakresie poza } \\
\text { lekcją }\end{array}$ \\
\hline Indywidualizowanie & Poza głównym nurtem lekcji & W głównym nurcie lekcji \\
\hline $\begin{array}{l}\text { Ukierunkowanie na } \\
\text { zmianę }\end{array}$ & $\begin{array}{l}\text { Unormalnienie ucznia - } \\
\text { zmiana podmiotu wobec } \\
\text { oczekiwań środowiska }\end{array}$ & $\begin{array}{l}\text { Normalizacja środowiska - } \\
\text { zmiana środowiska wobec } \\
\text { potrzeb podmiotu }\end{array}$ \\
\hline
\end{tabular}

Źródło: opracowanie własne.

Obie koncepcje pedagogiki specjalnej, w uproszczeniu sprowadzane tu do nurtów związanych z dysfunkcjonalnością indywidualną versus utrudnionym funkcjonowaniem społecznym, zakorzenione są w odrębnym ontologicznie sposobie postrzegania człowieka oraz rozumienia świata. To zaś utrudnia poszukiwania konsensusu (niemniej jednak podejście to znajdujemy w modelu bio-psychospołecznym) (Majewski 1999: 131), a zarazem próby takie naraża nie tylko na ontologiczną, ale także epistemologiczną, niewspółmierność.

Chociaż spory paradygmatyczne wydają się trudne do rozstrzygnięcia, to jednak obecne wizje pedagogiki specjalnej - bez względu na reprezentowaną opcję - ukazują ją jako naukę otwartą, korzystającą z dorobku nauk humanistycznych i społecznych, aczkolwiek powiązaną z naukami medycznymi (Krause 2010; Chrzanowska 2015).

W konsekwencji można przypuszczać, że pedagogika specjalna będzie rozwijała się dualnie. Pierwszy nurt, ukonstytuowany na tradycji medycznego postrzega- 
nia niepełnosprawności, zapewne silnie będzie czerpał z rozwoju nauk technicznych i medycznych, przesuwając granice sprawności indywidualnych w związku ingerencją $\mathrm{w}$ anatomiczną i fizjologiczną sferę człowieka. Rozkwit techniki być może wyznaczy nowe zadania pedagogiki specjalnej związane z zaniedbaniami i wypaczeniami rozwoju determinowanymi nadmiernym stosowaniem technologii. W rezultacie zmian mogą pojawić się nowe, nieobecne dziś lub małoistotne, zaburzenia (Zaorska 2017). Drugi - silniej związany ze społecznymi procesami konstruującymi i wzmacniającymi niepełnosprawność, pozostanie wierny konwencjom humanistycznym ukierunkowanym na wzmacnianie wartości osoby z niepełnosprawnością oraz budowanie kultury inkluzyjnej opartej na normalizacji środowiska.

Można zatem powiedzieć, że pierwszy nurt wpisuje się w rozkwit techniki i rozwój medycyny. Drugi - pozostaje w istotnym związku ze zintensyfikowanym zainteresowaniem osobami z niepełnosprawnością oraz poszukiwaniem społecznych rozwiązań, ukierunkowanych na normalizację ich życia oraz uznania prawa do pełnej autonomii.

Jakkolwiek zidentyfikowanie wskazanych perspektyw rozwoju pedagogiki specjalnej wydaje się stosunkowo proste, to już pytanie o wzajemne przenikanie się wiedzy generowanej w obu obszarach oraz jej międzyparadygmatyczną wędrówkę wydaje się trudniejsza do przewidzenia.

\section{Dwoistość pedagogiki specjalnej}

Dwoistość pedagogiki specjalnej, rozumianej jako nauki stosowanej, wpisuje się w postrzeganie pedagogiki konstruowane na kanwie relacji: teoria versus praktyka (czasem określanej mianem pedagogii). Przy czym silniejsze zakorzenienie pedagogiki specjalnej w naukach medycznych (aniżeli pedagogiki) sprzyjało znaczniejszemu jej upraktycznieniu. Nieco inaczej ujmując - jej podstawy teoretyczne, częściej ukonstytuowane na bazie funkcjonalnych teorii medycznych, współdecydowały o jej ateoretycznym charakterze $\mathrm{w}$ odniesieniu do koncepcji czerpanych $\mathrm{z}$ nauk humanistycznych i społecznych. Teza ta poprzedza stwierdzenie, że pedagogika specjalna jako subdyscyplina pedagogiczna była i jest bardziej praktyczna aniżeli inne subdyscypliny pedagogiczne. Jej dwoistość, jako całość złożona z dwóch powiązanych relacjami części, rozpostarta na osi napięć (nawiązuję tu do koncepcji dwoistości L. Witkowskiego 2001) między praktyką a teorią lokuje jej środek ciężkości bliżej praktyki. To zaś zachęca do formułowania przewidywań jej przyszłości w nieco innej perspektywie aniżeli pedagogiki ogólnie. W moim przekonaniu jest to szczególnie widoczne w obszarze konstruowanych koncepcji badawczych.

W kwestii konceptualizacji badań praktycznych na gruncie pedagogiki ukonstytuowały się dwa rozbieżne stanowiska. Pierwsze traktuje praktyczność jako konstytutywną i swoistą cechę badań pedagogicznych. W tej perspektywie proble- 
my praktyczne są immanentną częścią badań naukowych i zarazem stanowią ich społeczny sens. Badania te sprowadzają się najczęściej do diagnozy, która stanowi punkt wyjścia dla badań naprawczych (Pilch 1995: 48). Drugie stanowisko zasadza się na twierdzeniu, że podejście to odbiera pedagogice szansę na wypracowanie teorii badanych zjawisk. Wszak świadome ulepszania badanego fragmentu rzeczywistości wychowawczej (w tym także terapeutycznej) wymaga umiejętnego oddzielenia zbiorowego mniemania od struktur regulujących praktykę, a to zaś wymaga teorii, która te struktury opisuje (Konarzewski 2000: 86). Perspektywa ta bliska jest założeniu, że pedagogika powinna zrezygnować z niemożliwej do pełnienia roli projektującej, z roli przywódcy praktyki wychowawczej, porzucić zamiar zmieniania rzeczywistości, a zająć się nade wszystko opisem rzeczywistości wychowawczej. Nie oznacza to całkowitego kresu tego typu zadań, ale promowanie ich w sposób pośredni, z zastosowaniem technik perswazji - a nie przemocy (Hejnicka-Bezwińska 1995: 47). W tym ujęciu nauka i praktyka (edukacyjna, terapeutyczna) to zatem odrębne systemy, które funkcjonują według własnych reguł (Gajdzica 2011: 10).

Niemniej jednak praktyka edukacyjna:

- jest starsza niż nauka, którą powołano do jej wyjaśniania (Rubacha 2008: 26),

- była i jest jedyną racją uzasadniającą istnienie pedagogiki jako nauki (Hejnicka-Bezwińska 2008: 2010),

- oraz, że zadanie pedagogiki nie ogranicza się do projektowania zmian i przygotowania w trakcie studiów sprawnych techników, organizujących procesy wychowawcze, jej zadaniem jest także poznanie, wyjaśnienie istniejących zjawisk, obecnych w rzeczywistości wychowawczej (Bronk 2003: 59).

Dezyderat uprawiania pedagogiki jako nauki ukierunkowanej na poznanie pozwala na wyróżnienie dwóch typów pedagogiki. Umownie można nazwać je naukowym i perswazyjnym. Podejście naukowe domaga się uprawiania pedagogiki na wzór innych nauk empirycznych. Pozostawia ono normowanie praktyki wychowawczej na dalszym planie. Nastawienie perswazyjne umieszcza na pierwszym miejscu aksjologiczne i normatywne funkcje pedagogiki. Promowanie określonych ideałów i zachowań wychowawczych bierze tu górę nad wiedzą o faktycznych czynnikach i warunkach wychowania, ich przyczynach i skutkach, możliwościach i ograniczeniach (Bronk 2003: 59-60). W odniesieniu do pedagogiki specjalnej - sprzyja gruntowaniu praktyk terapeutycznych (immanentnie wpisanych w procesy opieki, wychowania i kształcenia) opartych na społecznej wiedzy potocznej, nierzadko niewspółmiernie nadbudowanej na teoriach medycznych.

Należy uznać zatem jako zasadne rozróżnienie pedagogiki jako nauki oraz praktyki edukacyjnej, traktując je jako dwa podsystemy świata kultury (Hejnicka-Bezwińska 2008: 2010). Są one powiązane licznymi relacjami, które mogą ujawniać się różnorodnymi związkami w koncepcjach badań nad socjalizacją i edukacją specjalną (w tym także integracyjną i inkluzyjną). Wyróżnienie badań praktycznych wydaje się więc możliwe, ale wyznaczenie jasnej i precyzyjnej granicy między nimi 
(w przypadku analizy pełnej koncepcji badawczej) a badaniami naukowymi jest zadaniem tylko pozornie łatwym, a przy tym o wątpliwej wartości z punktu widzenia budowania użytecznej koncepcji teoretycznej, służącej wyjaśnianiu okoliczności kształcenia, wychowania i terapii oraz przezwyciężaniu sytuacji trudnych dnia codziennego osób z niepełnosprawnością czy niedostosowaniem społecznym (Gajdzica 2011: 10-11).

Porzucenie jednej z dróg rozwoju pedagogiki specjalnej w przyszłości wydaje się niemożliwe, a zarazem niezasadne. Chociaż zainteresowanie badaniami podstawowymi w obszarze pedagogiki specjalnej wydaje się słabnąć, to jednak szansą na ich autentyczne podtrzymanie i rozwój jest wskazany we wstępie trend integracyjności nauk humanistycznych i społecznych znoszący sztuczne granice, a zarazem otwierający nowe perspektywy konstruowania teorii, także tej stosowalnej w praktyce. W obecnej sytuacji, przywołanego także we wstępie rozkwitu technologii, rozwija się natomiast zapotrzebowanie na badania wyrosłe z praktyk społecznych generujące nowe zjawiska niekorzystnie wpisujące się w szersze problemy społeczne.

\section{Zamiast zakończenia - międzydyscyplinarna wędrówka pojęć jako perspektywa znoszenia dualizmu i dwoistości pedagogiki specjalnej}

Niepełnosprawność jako jedna z podstawowych kategorii pedagogiki specjalnej przyjmuje postać sproblematyzowaną dopiero $\mathrm{w}$ zestawieniu $\mathrm{z}$ podmiotem nią obarczonym i otaczającymi go warunkami. Nadanie jej statusu: stanu, zjawiska, własności oraz uwzględnienie jej procesualności i zarazem dynamiki jako podstawy problemu naukowego, nie tylko zachęca, ale wręcz wymusza przekraczanie granic wiedzy dyscyplinarnej (Gajdzica 2017: 212-213). Otwarta nauka (także ta o niepełnosprawności) osiągnęła etap dojrzałości dzięki porzuceniu wąskich ram epistemologiczno-metodologicznych (Życiński 2013: 348).

Ostatnie dwie dekady to szczególny okres rozwoju zróżnicowanych paradygmatycznie formuł badawczych i konstruowanych w ich obszarze koncepcji służących poznaniu i zrozumieniu codzienności osób z niepełnosprawnością. Rozwój ten intensyfikuje wędrówkę pojęcia niepełnosprawności, początkowo zakorzenionego w medycznych i psychologicznych ujęciach funkcjonowania człowieka, a obecnie ujmowanego również $w$ kontekstach społecznych i kulturowych. Ilustrują to przemiany pedagogiki specjalnej inicjowane, między innymi, skierowaniem zainteresowań badaczy w stronę nie tylko tego, co wywołało, ale tego, co wywołuje niepełnosprawność - nadając jej dynamiczny wymiar (Gajdzica, Bełza, Prysak 2016: 9-10). Ten zaś, jak zauważa Reinhart Koselleck (2012), jest typowym objawem historycznej wędrówki wielu pojęć i łączy się z rozwojem nauki. Przykład ilustrujący tę wędrówkę został zobrazowany w tabeli 4 . 
Tabela 4. Perspektywy i aspekty postrzegania niepełnosprawności intelektualnej

\begin{tabular}{|c|c|c|}
\hline Z. Sękowska (1998: 2015) & $\begin{array}{l}\text { M.P. Malnoey i M.P. Ward } \\
\text { (za: Kowalik (1989: 2015) }\end{array}$ & O. Speck (2015: 47-66) \\
\hline $\begin{array}{l}\text { Podejście kliniczno- } \\
\text {-medyczne ukazujące } \\
\text { niedorozwój umysłowy jako } \\
\text { objaw choroby, ze szczegól- } \\
\text { nym zwróceniem uwagi na } \\
\text { etiologie i patogenezę. }\end{array}$ & $\begin{array}{l}\text { Perspektywa kliniczna, } \\
\text { w której niepełnosprawność } \\
\text { intelektualna traktowana } \\
\text { jest jako problem medyczny. } \\
\text { Jej przyczyną jest defekt } \\
\text { biologiczny w nieodwracal- } \\
\text { ny sposób uszkadzający } \\
\text { struktury i funkcje OUN. }\end{array}$ & $\begin{array}{l}\text { Aspekt medyczno- } \\
\text {-genetyczny - największe } \\
\text { znaczenie ma uszkodzenie } \\
\text { mózgu, które może skutko- } \\
\text { wać zaburzeniami rozma- } \\
\text { itych psychofizycznych } \\
\text { funkcji. }\end{array}$ \\
\hline $\begin{array}{l}\text { Podejście praktyczne } \\
\text { o charakterze prawno- } \\
\text {-administracyjnym, np. } \\
\text { definicja z angielskiej ustawy } \\
\text { o zdrowiu psychicznym } \\
\text { z } 1959 \text { r. włączająca niedo- } \\
\text { rozwój umysłowy do } \\
\text { zaburzeń psychicznych. }\end{array}$ & $\begin{array}{l}\text { Perspektywa rozwojowa } \\
\text { utożsamiająca niepełno- } \\
\text { sprawność intelektualną } \\
\text { z niepowodzeniem } \\
\text { w rozwoju człowieka, który } \\
\text { uwarunkowany jest czynni- } \\
\text { kami biologicznymi i } \\
\text { środowiskowymi. }\end{array}$ & $\begin{array}{l}\text { Aspekt psychologiczny - to } \\
\text { przede wszystkim obniżenie } \\
\text { poziomu rozwoju intelektu- } \\
\text { alnego, ale również zaburze- } \\
\text { nia zachowania, trudności } \\
\text { adaptacyjne, na co wpływają } \\
\text { także uwarunkowania } \\
\text { społeczne i kulturowe. }\end{array}$ \\
\hline $\begin{array}{l}\text { Podejście psychologiczne } \\
\text { różniące się liczbą oraz } \\
\text { rodzajem kryteriów, według } \\
\text { których ocenia się ten stan } \\
\text { (np. poziom określonych } \\
\text { sprawności, zaburzeń, } \\
\text { zdolności). }\end{array}$ & $\begin{array}{l}\text { Perspektywa społeczna } \\
\text { ukazująca upośledzenie } \\
\text { umysłowe jako fakt społecz- } \\
\text { no-kulturowy. Niepełno- } \\
\text { sprawność traktowana jest } \\
\text { jako stan nabyty w toku } \\
\text { interakcji społecznych / } \\
\text { wynalazek społeczny. }\end{array}$ & $\begin{array}{l}\text { Aspekt socjologiczny i } \\
\text { pedagogiczny - uwydatnia } \\
\text { znaczenie socjalizacji, } \\
\text { związki z pochodzeniem } \\
\text { społecznym i innymi } \\
\text { mechanizmami społecznymi, } \\
\text { m.in. ekskluzji, dyskrymina- } \\
\text { cji, a także wychowania } \\
\text { i kształcenia w kształtowa- } \\
\text { niu się obrazu niepełno- } \\
\text { sprawności intelektualnej. }\end{array}$ \\
\hline
\end{tabular}

Żródło: opracowanie własne.

Międzydyscyplinarna wędrówka pojęcia niepełnosprawności nie może jednak oznaczać dowolnego łączenia odmiennych ontologicznie koncepcji i bezrefleksyjnego przenoszenia dorobku jednej dyscypliny w obszar drugiej z niedostrzeganiem istoty dorobku tradycji metodologicznych poszczególnych dziedzin i dyscyplin naukowych. Podobnie - nie wszystkie niewspółmierne koncepcje, budujące dorobek pedagogiki specjalnej mogą konstytuować jeden wspólny opis rzeczywistości osób z niepełnosprawnością czy niedostosowaniem społecznym (Gajdzica 2017: 212-213). To jednak nie wyklucza ich wzajemnego przenikania się i otwierania nowych pól badawczych. Jako przykład takich konwersji można podać zagadnienia 
rozpatrywane w zakresie socjologii medycyny czy bioetyki. Dwoistość oraz dualność pedagogiki specjalnej warto zatem postrzegać jako szansę jej wieloparadygmatycznego rozwoju.

\section{Bibliografia}

Archer M. S. (2013) Człowieczeństwo. Problem sprawstwa, tłum. A. Dziuban, Kraków, Zakład Wydalniczy „NOMOS”.

Bronk A. (2003) Czy pedagogika jest naukq autonomicznq? w: W trosce o integralne wychowanie, M. Nowak, T. Ożóg, A. Rynio (red.), Lublin, Wydawnictwo KUL.

Chrzanowska I. (2015) Pedagogika specjalna. Od tradycji do współczesności, Kraków, Oficyna Wydawnicza „Impuls”.

Doroszewska J. (1989) Pedagogika specjalna, Wrocław, Warszawa, Kraków, Gdańsk, Łódź, Zakład Narodowy im. Ossolińskich.

Dykcik W. (1998) Pedagogika specjalna i ogólna - wzajemne relacje teoretyczno-poznawcze i edukacyjne w: Tożsamość polskiej pedagogiki specjalnej u progu XXI wie$k u$ J. Pańczyk (red.), Warszawa, Wydawnictwo WSPS, s. 115-132.

Dykcik W. (2005) Wprowadzenie w przedmiot pedagogiki jako nauki w: Pedagogika specjalna, W. Dykcik (red.), Poznań, Wydawnictwo UAM, s. 13-66.

Gajdzica Z. (2010) Przemiany pedagogiki specjalnej a jej miejsce $w$ akademickim kształceniu pedagogów różnych specjalności w: Studia z teorii i historii wychowania oraz nauk pokrewnych, U. Szuścik (red.), Katowice, Wydawnictwo UŚ, s. 267-276.

Gajdzica Z. (2011) Sytuacje trudne w opinii nauczycieli klas integracyjnych, KrakówKatowice, Wydawnictwo UŚ - Kraków, Oficyna Wydawnicza „Impuls”.

Gajdzica Z. (2017) Wybrane pułapki niewspółmierności w badaniach świata osób $z$ niepełnosprawnościq w: Pułapki epistemologiczne i metodologiczne $w$ badaniach nad edukacjq. Jak sobie z nimi radzić?, M. Dudzikowa, S. Juszczyk (red.), s. 212-223.

Gajdzica Z., Bełza M., Prysak D. (2016) Wprowadzenie, „Problemy Edukacji, Rehabilitacji i Socjalizacji Osób Niepełnosprawnych", t. 23, s. 9-10.

Hejnicka-Bezwińska T. (1995) Edukacja, kształcenie, pedagogika (Fenomen pewnego stereotypu), Kraków, Oficyna Wydawnicza „Impuls”.

Hejnicka-Bezwińska T. (2008) Pedagogika ogólna, Warszawa, WAiP. 
Hejnicka-Bezwińska T. (2013) Tożsamość pedagogiki w warunkach „wielkiej zmiany kulturowej”, „Rocznik Pedagogiczny”, t. 36, s. 35-55.

Konarzewski K. (2000) Jak uprawiać badania oświatowe. Metodologia praktyczna, Warszawa, WSiP.

Koselleck R. (2012) Semantyka historyczna, tłum. W. Kunicki, Poznań, Wydawnictwo Poznańskie.

Kowalik S. (1989) Upośledzenie umysłowe, Warszawa-Poznań, PWN.

Krause A. (2010) Współczesne paradygmaty pedagogiki specjalnej, Kraków, Oficyna Wydawnicza „Impuls".

Lewowicki (2000) Miejsce pedagogiki specjalnej w naukach pedagogicznych na przełomie drugiego i trzeciego tysiąclecia w: Pedagogika specjalna lat dwutysięcznych, J. Pańczyk (red.), Łódź, Wydawnictwo Dajas, s. 9-16.

Lewowicki T. (2012) Tożsamość pedagogiki - tradycja, współczesność, nowa tożsamość?, „Cieszyński Almanach Pedagogiczny”, nr 1, s. 11-24.

Majewski T. (1999) Biopsychospołeczna koncepcja niepełnosprawności, „Szkoła Specjalna", nr 3, s. 131-134.

Piasecki M., Besowski S., Czech R. (1998) Społeczny model niepełnosprawności, „Problemy Rehabilitacji Społecznej i Zawodowej", nr 1, s. 47-52.

Pilch T. (1995) Zasady badań pedagogicznych, Warszawa, Wydawnictwo Akademickie „Żak”.

Rieser R. (2013) The Struggle for Inclusion: The Growth of a Movement in: Disability Politics \& The Struggle for Change, L. Barton (ed.), London and New York, Routledge Taylor \& Francis Group: 132-148.

Rubacha K. (2008) Metodologia badań nad edukacja, Warszawa, WAiP.

Sękowska Z. (1998) Wprowadzenie do pedagogiki specjalnej, Warszawa, Wydawnictwo WSPS.

Słownik języka polskiego, t. 1. (1992) Warszawa, PWN.

Speck 0. (2015) Osoby z niepełnosprawnościq̨ intelektualnq. Podręcznik dla celów wychowawczych i edukacyjnych, tłum. G. Grzywna-Tuk, Gdańsk, Harmonia Universalis.

Witkowski L. (2001) Dwoistość w pedagogice Bogdana Suchodolskiego (z aneksem o Sergiuszu Hesenie), Kraków, Wydawnictwo WIT-GRAF. 
Zaczyński W. P. (1988) Metodologiczna tożsamość dydaktyki, Warszawa, WSiP.

Zaorska M. (2017) Przyszłość pedagogiki specjalnej - perspektywa transhumanistyczna, bioetyczna i postdarwinowska, w: Szkoła $w$ warunkach zmiany społecznej i kulturowej. Edukacja przyszłości, B. Gofron, P. Migała (red.), Warszawa, Wydawnictwo SGGW, s. 141-149.

Życiński J. (2013) Struktura rewolucji naukowej. Studium rozwoju współczesnej nauki, tłum. M. Furman, wstęp M. Heller, Kraków, Copernicus Center Press. 